\title{
DETERMINANTS OF FOREIGN INVESTMENTS IN RESIDENTIAL PROPERTIES: EVIDENCE FROM MALAYSIAN STATES
}

\author{
Hassan Fereidouni GHOLIPOUR \\ Center for Real Estate Studies (CRES), Faculty of Geoinformation \& Real Estate, Universiti \\ Teknologi Malaysia (UTM), 81310 Johor, Malaysia \\ E-mail: hassanhgf@gmail.com
}

Received 19 March 2012; accepted 27 June 2012

\begin{abstract}
The last decade has witnessed a strong growth in foreign investments in residential properties (FIRP) in Malaysia. However, FIRP is not equally distributed among Malaysian states. Hence, this warrants an investigation into why some states have larger FIRP than others. The purpose of this paper is to investigate the pattern and determinants of FIRP in Malaysian states. FIRP in Malaysia has been agglomerated in the major and industrialized states (such as Kuala Lumpur, Selangor, Pulau Pinang and Johor). Using a panel of 14 Malaysian states over a period of 7 years (2004-2010) and applying the system Generalized Method of Moments (GMM) approach, the statistical results show that tourism agglomeration (learning about the host location), well-being of the local people, foreign investments in other sectors, religious diversity and minimum property purchase price are important determinants of FIRP.
\end{abstract}

KEYWORDS: Residential property; Foreign investments; Tourism; Religious diversity; Malaysia; GMM

REFERENCE to this paper should be made as follows: Gholipour, H. F. (2013) Determinants of foreign investments in residential properties: evidence from Malaysian states, International Journal of Strategic Property Management, 17(3), pp. 317-332.

\section{INTRODUCTION}

The last decade has witnessed a strong growth in foreign investments in residential properties (FIRP) in Malaysia. The FIRP has recorded impressive growth during the 2000-2010 period, with the annual growth rate of $25 \%$ (see Figure 1). In 2000, FIRP was only $\mathrm{RM}^{1}$ 204 million while it reached to around RM 1.4 billion in 2010. Moreover, FIRP accounts for $65 \%$ of total foreign investments in Malaysia' property market.

Since opening the country to foreigners, investors from Singapore, United Kingdom

1 Malaysian currency is the Ringgit. Exchange rate is around US\$1 = RM3 as of October 2011.
(UK), Korea, United States (U.S.), India, Japan and China have been the biggest buyers in Malaysia's property market. More recently, Malaysia's property market has attracted a large number of investors from Middle East countries mainly due to uncertainty in the Middle East region as well as the availability of Islamic finance in Malaysia (Propertywire, 2011).

Despite Malaysia has attracted a large amount of FIRP in general, however, FIRP is not equally distributed among Malaysian states. Figure 2 shows the locational distribution of FIRP in 2004 and 2010 for Malaysian states. FIRP has been disproportionately concentrated in the major states (Kuala Lumpur, 


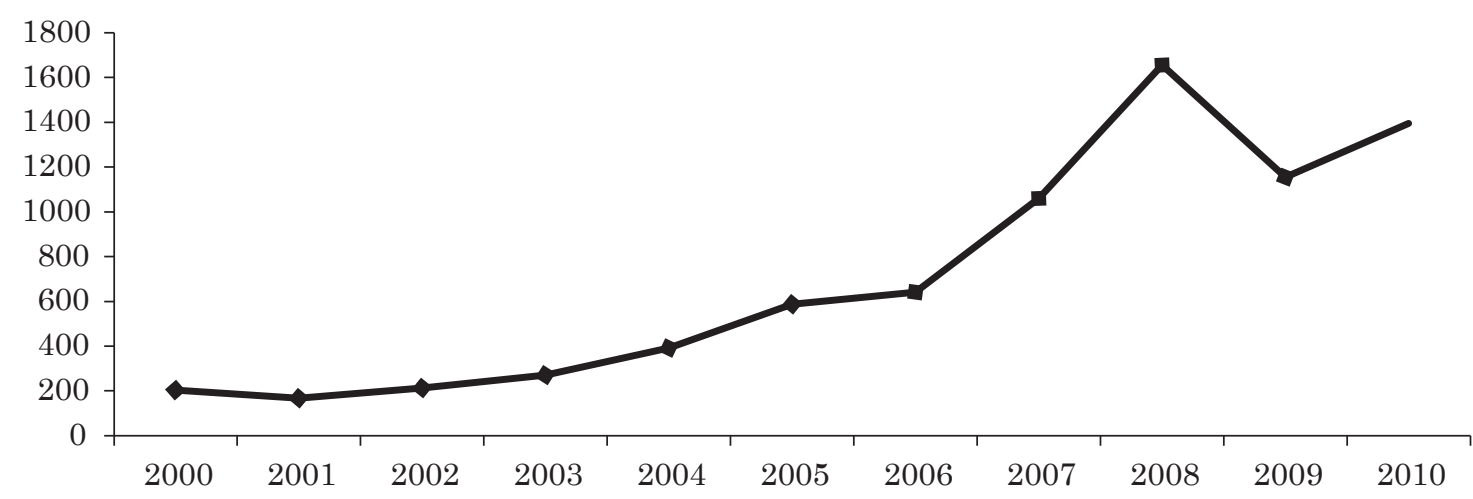

Figure 1. Evolution of residential property investments by foreigners in Malaysia, 2000-2010 (RM millions)

Source: Valuation and Property Service Department, Malaysia's Ministry of Finance

Selangor, Pulau Penang and Johor). Hence, this warrants an investigation into why some states have larger FIRP than others. The purpose of this study is to understand the driving forces of FIRP locations in Malaysia by using data on FIRP in Malaysian states during 2004-2010.

Our paper contributes to the literature on foreign investments in real estate and provides some implications for Malaysian policymakers. Firstly, to our knowledge, no studies have specifically explored the location patterns and determinants of FIRP in Malaysia's real estate market. Most studies in this area cover developed countries and China. Since findings for these countries might not be directly transferable to a small emerging economy such as Malaysia, therefore, more work is necessary to obtain a clearer picture of the determinants of FIRP in Malaysia. Secondly, most of the past literature only focuses on determinants of aggregate foreign direct investment (FDI) in real estate sector and they did not disaggregate real estate data into sub-sectors such as residential or commercial. However, in the present study we only consider residential properties for analysis. Thirdly, identifying the factors affecting the involvement of international real estate investors is important for policymakers seeking to encourage foreign participa- tion in their respective property markets. In other words, enhancing location-specific factors which favor FIRP as will be highlighted in this study increases the probability of a Malaysian state being favored over its competitors in the foreign investment competition. Finally, given the large decrease in the shares of FDI flows into the Malaysian's manufacturing sector in recent years, attracting FDI in services (including real estate) has received a lot of attentions by the government of Malaysia. Hence, our results would provide some useful insights for Malaysian policymaker in order to attract larger amount of foreign investments in real estate sector.

The rest of this paper is presented as follows. Section 2 explains the trend of foreign investments in Malaysia's residential properties. The advantages and disadvantages of foreign investments in property sector for host location are discussed in Section 3. Section 4 summarizes some of the previous studies. Section 5 provides the theoretical understanding of foreign real estate investments (FREI) location and proposes various factors which could determine FIRP. Section 6 explains the econometric methodology. Section 7 presents the empirical results and finally Section 8 concludes this paper. 

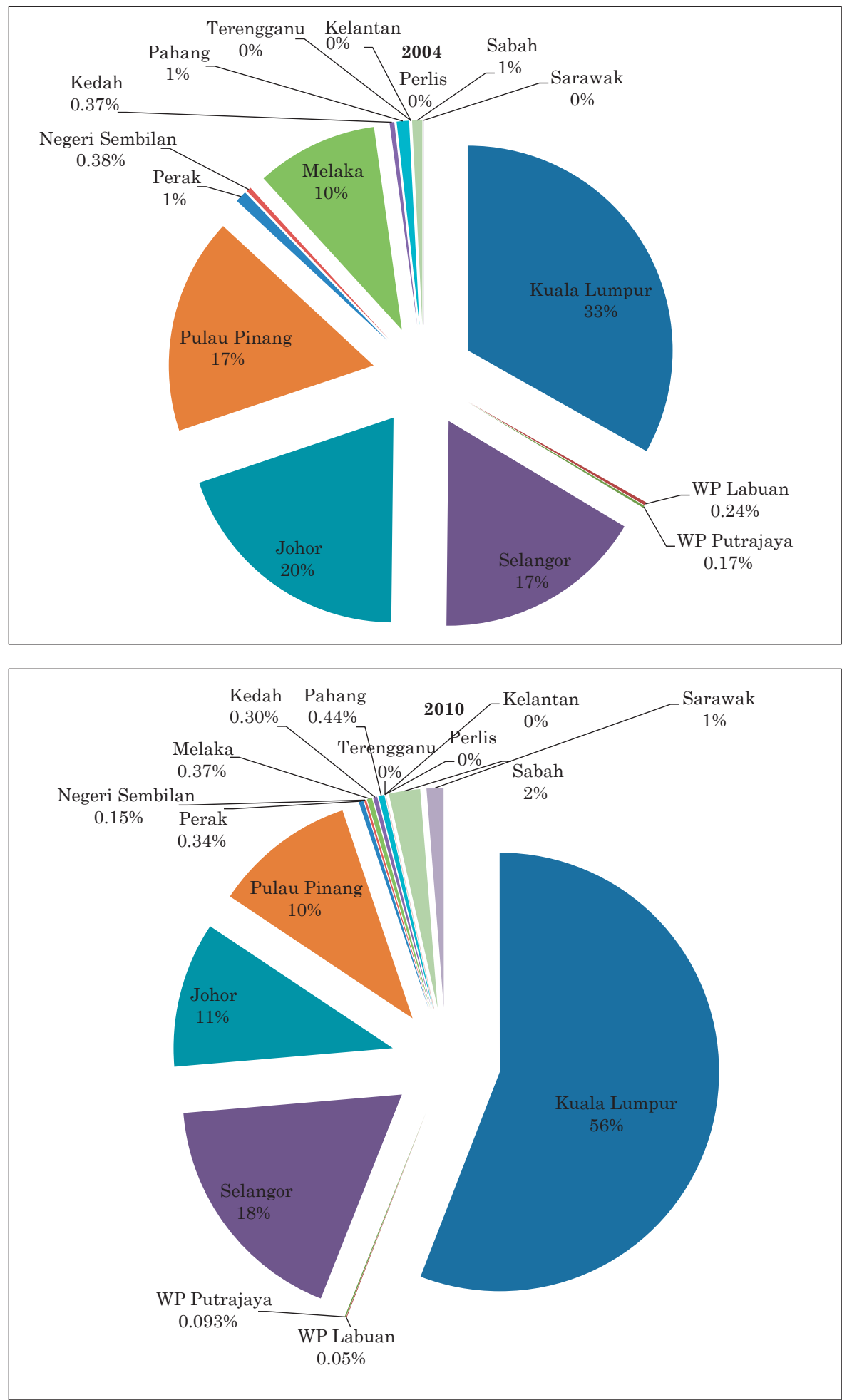

Figure 2. Locational distribution of FIRP (above 2004; bottom 2010) 


\section{REVIEW OF FOREIGN INVESTMENT IN MALAYSIA'S RESIDENTIAL PROPERTIES}

Attracting greater among of foreign real estate investment in the Malaysia's property market is one of the long running plans of government of Malaysia to reach fully developed nation status by 2020. Among these policies, the Malaysia My Second Home (MM2H) program is one of the most attractive plans which was launched in 2002. It is an international residency plan enacted by the government of Malaysia to allow foreigners to live in the country on a long-stay visa of up to 10 years $(\mathrm{MM} 2 \mathrm{H}$, 2011). In fact, this program is an effort on the part of the Malaysian government to draw foreign capital and property investors into the country. According to MM2H (2011), more than 15,000 applications have been approved under this program since 2002. China, Bangladesh, UK, Japan and Iran are the top five countries that have highest number of MM2H holders in Malaysia from 2002 to 2010 (see Table 1). Interestingly, most of the $\mathrm{MM} 2 \mathrm{H}$ participants have purchased residential properties in Malaysia. According to the survey done by the Expat, Davison (2011) revealed that 83\% of the expatriates which includes the MM2H participants have committed to an average of RM 830,000 for property purchase in Malaysia (Lee et al., 2010).

Table 1. Top 10 countries involved in MM2H in Malaysia (2002-2010)

\begin{tabular}{ll}
\hline Countries & Total number (2002-2010) \\
\hline China & 2733 \\
Bangladesh & 2027 \\
United Kingdom & 1754 \\
Japan & 1512 \\
Iran & 983 \\
Singapore & 789 \\
Taiwan & 702 \\
Pakistan & 653 \\
India & 622 \\
Republic of Korea & 596 \\
Others & 4237 \\
\hline
\end{tabular}

Source: http://www.mm2h.gov.my/statistic.php
Prior to launching the MM2H program in 2002, government of Malaysia enacted Silver Hair program (1996-2001) to enable foreigners to purchase home and stay in Malaysia on a long-stay visa with specify financial and medical criterion qualifications (Lee et al., 2010). This program targeted on foreign retirees aging 65 and above only. As can be seen from Table 2, citizens from UK, Singapore, Taiwan, Japan and China were among the most active participants in this program.

Table 2. Top 10 countries involved in Silver Hair Program in Malaysia (1996-2001)

\begin{tabular}{ll}
\hline Countries & Total number (1996-2001) \\
\hline United Kingdom & 164 \\
Singapore & 118 \\
Taiwan & 99 \\
Japan & 79 \\
China & 47 \\
Indonesia & 45 \\
India & 24 \\
Pakistan & 7 \\
Republic of Korea & 5 \\
Others & 240 \\
\hline
\end{tabular}

Source: http://www.mm2h.gov.my/statistic.php

With reference to the history of foreign investments in Malaysia's property sector, it is observed that land legislation and foreign ownerships rules have been amended several times in the last three decades. In other words, the development of policy on foreign acquisition of Malaysian properties has been inconsistent. On one hand, Malaysian policymakers have aimed to protect Malaysian interests by restricting foreign ownership in landed properties, and on the other hand the foreign acquisitions of Malaysian properties have been welcomed during the economic downturn to stimulate the economy (Tan, 1998).

In 1984, the National Land Code (NLC) prohibited foreigners from buying landed property in Malaysia. This act came after a major property boom before 1984. However, after three years (1987), the NLC allowed foreigners to invest in properties in order to provide an impetus to the failing economy due to the world recession during those years. When the 
economy of Malaysia picked up in 1988/1989, the volume of property transactions and prices paid for properties by foreigners started rising. In 1991, due to intense speculations in property market, government of Malaysia restricts foreign ownership of landed properties. In June 1994, the NLC regulated a new set of guidelines which was used uniformly in all Malaysian states. The guidelines for residential properties can be summarized as follow: foreigners could buy condominium of value exceeding RM 250,000 and holiday homes on condition that this should not exceed $30 \%$ of each block. In addition, foreigners could buy but not more than $10 \%$ bungalow and semidetached in any development. If a development is envisaged then a local company with local equity of $40 \%$ (including 30\% Bumiputra) must be set up. On the other hand, foreigners could not buy terrace houses of two storey and below, low cost and medium cost apartments, flats, condominiums priced below RM 250,000 and Bumiputra ${ }^{2}$ quotas (Mani, 2006).

With effective from 1 January 2010, foreigners are allowed to purchase properties above RM 500,000 for most of the states in Malaysia, and it is differ from state to state. Similar to the rules before 2010, property on Malay reserved land cannot be owned by overseas foreign investors. Moreover, foreigners are not allowed to acquire residential units valued less than RM 250,000 per unit and residential units under the category of low and lowmedium cost (Economic Planning Unit, 2010).

\section{THE IMPACTS OF FOREIGN INVESTMENTS IN REAL ESTATE ON THE HOST LOCATION}

Horner and Swarbrooke (2004) list several potential economic benefits when foreigners buy property in a host location: (1) bringing new life to the rural communities suffering depopulation; (2) making local services viable (such as food shops, transport, restaurants, and sport-

2 Bumiputra is a Malay term widely used in Malaysia, embracing indigenous people of the Malay Archipelago. It should be noted that Malaysia is a multi-ethnic, multicultural and multilingual society (including indigenous tribes, Malays, Chinese and Indians). ing facilities); (3) income for local entrepreneurs from the spending by the foreign owners; (4) property taxes paid to the local government; (5) profits from land owned by local people; (6) jobs and income for local builders and craftsmen. Moreover, foreign investments can contribute significantly to the rapid globalization of metropolises and facilitates change the scene of urban development qualitatively (Wei et al, 2006; Wu, 2001). Basu and Yao (2009) show that real estate investment by foreign firms leave a favorable impact on the enrollment in higher education (through higher demand for property analyzers and architecture). Fung et al. (2010) argue that investment in real estate sector by domestic and foreign investors is a major driver of economic growth, by stimulating the demand for many other industries such as electronics, machinery, steel and architecture. Similarly, Weagraff (2004) find that second home investments are a viable rural economic development tool and have a positive influence on population, income and employment growth.

On the other hand, the growth of foreign property buying can also bring negative impacts to host communities such as: (1) local people can begin to feel like outsiders in their home community; (2) the local people may suffer at the present of many foreign owned second homes because these homes may be occupied by local people; (3) it will push up the prices in the local property market (Horner and Swarbrooke, 2004).

\section{LITERATURE REVIEW}

There are several studies in the literature on determinants of foreign investments in real estate sector. In this section, the most relevant studies are reviewed.

Edgington (1996) examined the location and type of Japanese property investments in Canada in the late 1980s. By using unpublished official statistics and company interviews, he highlighted the importance of Japanese perceptions and local opportunities and constraints in 
shaping the geography of Japanese real estate investments in Canada.

Ford et al. (1998) investigated factors motivating foreigners to purchase different types of real estate (apartment, office, retail and industrial) applying a conditional logit model. Their findings concluded that sector's activity level, profitability, risk, rents and capitalizations all significantly affect the probability that any real estate type is chosen by foreign real estate investors.

Moshirian and Pham (2000) analyzed those factors which contributed to the expansion of U.S. FDI in real estate abroad over the period 1985-1995. By applying GMM estimation method, their empirical results showed that U.S. financial wealth, U.S. FDI in manufacturing and banking, bilateral trade between the U.S. and her major trade partners, foreign current account balance and U.S. foreign financial liabilities contribute positively to the expansion of U.S. FDI in real estate abroad. In addition, they found that as returns from the U.S. stock market decline, there are more incentives for U.S. investors to invest in foreign real estate.

A semi-structured questionnaire survey for twelve foreign real estate developers operating in Shanghai in 2002 was conducted by Zhu et al. (2006) to find out the main reasons for entering the real estate market of Shanghai. Their survey results showed that the main reasons for foreign real estate investors and developers to attend in Shanghai real estate market ranked as follow: potential of the market, company's development strategy, penetration into new market, establishment of foothold in the market, accumulation of experience in the market, geographic location, gaining a dominant position, tax incentives provided by the host city, diversification of investment, obtaining immediate profit and exchange rate. They also concluded that FREI would be attracted to regions with a potential to generate higher returns to capital.

Through a questionnaire survey on property consultants, Chin et al. (2006) studied the factors that are of importance in attracting local and international property investments in Southeast Asian cities' real estate markets. Their analysis showed that the respondents regarded sound and financial economic structure, strength and stability of the economy, restrictions and regulations on foreign investors, political stability and legal regulation as the most important issues affecting the market attractiveness. Furthermore, their results indicated that taxation, legal framework, liberalization of the financial market, currency stability and convertibility, the transparency of the legislative system, level of public infrastructure, market transparency, level or professionalism, government interventions, perceived corruption level and the urban form were found important for property investors.

Lai and Fischer (2007) surveyed 40 foreign investors that had invested in real estate in Taiwan from 1997 to 2003 in order to identify the factors that could explain foreign investors' selection criteria when they decide to invest in Taiwan. By using a multi-criteria decision model (Analytic Hierarchy Process), they found that the ranking of priorities for foreign real estate investment firms is lead by economic, policy, market, social and product factors respectively. More specifically, their results suggested that operational risk, market size, land costs, national competitiveness, national competitiveness, political stabilities, language communications, economic development, and government's restrictions on investment in real estate market are the most important criteria when investors are making an international investment in Taiwan.

He et al. (2009) empirically investigated the location patterns and determinants of FDI in China's real estate industry. Their spatial analysis of FDI in China's real estate development showed that coastal provinces including Hainan, Zhejiang, Liaoning, Beijing and Shanghai were relatively attractive to foreign real estate investors. Using data on FDI inflows in real estate in Chinese provinces during 1997-2007 and applying a panel data regression model, 
their statistical results indicated that firstly, foreign investors in China's real estate development follow their customers to Chinese provinces and pursues local profit opportunities as well. Secondly, foreign real estate investors avoid high labor cost provinces and financing cost but significantly favor provinces with higher housing prices. Thirdly, foreign real estate investors are attracted to provinces with developed land and housing commercialization, good governance, strong law enforcement and developed services.

Falkenbach (2009) studied which criteria investors use for selecting the international markets they invest in Finland. Using a questionnaire survey among real estate investors (who have performed international property investments in Europe), their results indicated that the most important factors for market selection ranked as safety of title/property rights, expected return on property investments, liquidity of property markets, market size, taxation, availability of professional services in real estate sector, expected economic growth in the country/area, availability of market information and performance benchmarks, geographical nearness of markets to other target markets, existence of indirect investment possibilities, diversification possibilities through low correlation of returns and existence of other foreign players in the market.

He and Zhu (2010) analyzed the spatial patterns and determinants of FDI in real estate development in 35 major Chinese cities during 2002-2008. Using a panel dataset (applying fixed-effect panel analysis), their results indicated that both local demand and demand generated by foreigners for real estate has attracted foreign real estate developers. Moreover, they found that foreign developers favored cities that had invested heavily in their real estate industries and also cities with more developed land market and more liberalized economies.

Rodríguez and Bustillo (2010) examined the determinants of foreign real estate investment inflows for Spain over the period 1990-2007, applying Engle-Granger cointegrating Regressions. Based on the elective model, they concluded that GDP per capita, expected capital gains, travel costs, tourism agglomeration and housing prices are relevant factors explaining FREI in Spain.

Anop (2010) studied the determinants of FREI in 15 developed OECD countries of European area. Based on a panel data analysis for the period of 1996-2007, her empirical findings showed that GDP (as a measure of market size), human capital development and better road infrastructure proved to be important in attracting foreign capital into the real estate sector. She further found that economic growth in these countries did not contribute positively to the expansion of FREI.

Gholipour et al. (2010) used a multivariate cointegration approach to examine the interaction between Iranian investment in Dubai's real estate sector (IIDRE) and Iranian tourism agglomeration in Dubai and concluded that in the long-run the causation runs from tourism agglomeration to IIDRE. It means that agglomeration of Iranian knowledge about attractiveness of Dubai as a holiday destination is an important factor explaining IIDRE.

In a subsequent study, Gholipour and Masron (2011) examined the effect of tourism agglomeration (learning about the host location) on foreign real estate investment (FREI) in OECD countries. Using a fixed-effect panel data method, their results showed that tourism agglomeration is positively and significantly associated with FREI. Moreover, they found that countries with higher level of GDP (larger market size) attract greater amount of FREI.

As it is apparent from existing literature, there are limited studies on determinants of foreign investment in Malaysian real estate sector. Moreover, most of them used aggregate FDI in real estate rather than using disaggregate data (e.g. residential, commercial) for analyzing the determinants of foreign investment in real estate sector. Our study would fill these gaps. 


\section{THEORETICAL BACKGROUND AND VARIABLE SELECTION}

Most studies on sector FREI have been based on the following theories as a means of measuring the most significant determinants of FREI: (1) determinants of FDI in the ownership, location and internalization advantage (OLI) framework or eclectic theory, (2) portfolio theory, and (3) following the client hypothesis. For example, Ford et al. (1998) and Holsapple et al. (2006) argued that FREI is often hybrids that have characteristics of both foreign portfolio investment and FDI. Similarly, Jiang et al. (1998) discussed that while most foreign investment in real estate is classified as direct investment however it shares most of the characteristics of portfolio investment. Findings of Moshirian and Pham (2000) on U.S. FDI in real estate abroad indicated that following the client hypothesis, the risk diversification strategy and eclectic model are relevant theories to explain FREI. Following the customers, returns to capital and conducive institutions are the factors that foreign investors in China's real estate industry stress (He et al., 2009). Bardhan and Kroll (2007) mentioned that motivations for globalization of real estate investment include diversification of risk, higher returns and changing customer demand. Similarly, Worzala (1994) and Newell and Worzala (1995) concluded that the two important rationales for conducting international real estate investments are diversification benefits and possibilities to achieve higher returns for investments. He et al. (2009) argued that international real estate investors are largely local market seeking and stressing the importance of local market conditions. Similarly, Zhu et al. (2006) noted FREI is deemed local economic activities because of its heterogeneity, low liquidity, and high transaction costs and location fixity. Rodríguez and Bustillo (2010) concluded that the eclectic approach may be viewed a more complete way to look for determinants of FREI.
Therefore, it can be concluded that FREI (similar to FDI in services and manufacturing $^{3}$ ) should be explained by combination of existing theoretical models. In other words, from each of the existing models, a number of determinants can be extracted. This is in line with Rodríguez and Bustillo (2010).

The variables that are considered for the empirical analysis of the present study are set out in this section. The choice of variables is guided by three considerations: the availability of data, the relevance of the variables in question from a theoretical and empirical perspective and the need for a parsimonious specification imposed by the relatively small size of the available sample.

The following factors (based predominantly on the OLI theory, portfolio theory and following the client hypothesis) have been chosen as describing a model of the determinants of FIRP in Malaysia: infrastructure, foreign investments in other sectors, property prices, tourism, well-being of local people, religious diversity and minimum property purchase price.

It should be noted that the relationships between infrastructure, well-being of local people, and religious diversity, tourism agglomeration and FIRP are explained by locational perspective of OLI theory. The relationship between foreign investments in other sectors and FIRP is explained by following the client hypothesis. Finally, the relationships between property price, minimum property purchase price and FIRP are explained by portfolio theory. A summary of variables are described in Table 3.

\subsection{Dependent variable}

Foreign Investments in Residential Properties. As the dependent variable, foreign investments in residential properties (FIRP) per capita will be used. Per capita values allow us to take the relative state size into account. The FIRP data

3 For more discussion, refer to Faeth (2009) and Ramasamy and Yeung (2010). 
Table 3. Variables-description and sources

\begin{tabular}{|c|c|c|c|}
\hline Variable & Description & $\begin{array}{l}\text { Proxy for /actual } \\
\text { measure }\end{array}$ & Source \\
\hline FIRP & $\begin{array}{l}\text { Foreign investments in residential } \\
\text { properties }\end{array}$ & Actual measure & $\begin{array}{l}\text { Valuation and Property Service } \\
\text { Department, Malaysia's Ministry of } \\
\text { Finance }\end{array}$ \\
\hline INFRAS & Registered vehicles & $\begin{array}{l}\text { Proxy for } \\
\text { infrastructure }\end{array}$ & $\begin{array}{l}\text { Road Transport Department of } \\
\text { Malaysia }\end{array}$ \\
\hline FDI & $\begin{array}{l}\text { Foreign investment in other } \\
\text { sectors }\end{array}$ & Actual measure & $\begin{array}{l}\text { Valuation and Property Service } \\
\text { Department, Malaysia's Ministry of } \\
\text { Finance }\end{array}$ \\
\hline PPRICE & Housing price index & Actual measure & $\begin{array}{l}\text { Valuation and Property Service } \\
\text { Department, Malaysia's Ministry of } \\
\text { Finance }\end{array}$ \\
\hline TOUR-1 & $\begin{array}{l}\text { Tourism agglomeration (number of } \\
\text { international tourists, but lagged } \\
\text { one period) }\end{array}$ & Actual measure & Ministry of Tourism Malaysia \\
\hline GDPcap & GDP per capita & $\begin{array}{l}\text { Proxy for well-being } \\
\text { of local people }\end{array}$ & Malaysia's Department of Statistics \\
\hline RELIG & Religious diversity & Actual measure & Author's calculation \\
\hline MMP & Minimum purchase prices & Actual measure & Davison (2011) \\
\hline
\end{tabular}

are from the Valuation and Property Service Department, Malaysia's Ministry of Finance.

\subsection{Explanatory variables}

Infrastructure. The previous studies on foreign investment in properties stress the importance of the infrastructure. For example, Ramasamy and Yeung (2010) showed a positive and significant result proving that countries that have an established infrastructure would attract greater amounts of FDI in service sectors (including real estate). Renaud (2010) argued that infrastructure development was one of the major factors that attract foreign investors in Dubai's real estate sector. Similarly, Chin et al. (2006) found that level of public infrastructure was one of the important factors for property investors in Southeast Asian cities' real estate markets. On the other hand, Anop (2010) showed that infrastructure was negatively associated with FDI inflows in real estate, suggesting that foreign investors invest less in the countries which have achieved a certain level of development. Lai and Fischer
(2007) found that foreign firms in real estate show little concern for infrastructure because they provide their own infrastructure. Given the above, we expect a relationship between the level of infrastructure and FIRP. As a proxy for infrastructure, the registered vehicles are used. Information on registered vehicles is taken from the Road Transport Department of Malaysia. The registered vehicle is the only available infrastructure data that we could collect across states and over time.

Foreign Investment in Other Sectors. Another hypothesis to be tested is the relationship between foreign investment in other sectors and FIRP. It is expected that as the foreign investors (in manufacturing and services sector) expand their operations in the host country, their demand for investments in real estate in that host country will increase as well. Moshirian and Pham (2000) found that U.S. FDI in real estate abroad is positively correlated with U.S. FDI in manufacturing and banking abroad. In other words, their results implied that expansion of U.S. investment in the form of manufacturing and banking 
contributes to U.S. investment in real estate abroad. Similarly, Hines (2001) documented that as industrial and financial firms expand their operations overseas, they require properties (industrial, commercial, residential real estate) by acquisition or lease that fit their particular corporate needs (such as carrying on their international business and house their employees). He et al. (2009) also argued that foreign investors in real estate industry follow their customers (such as international business personnel) to the host economies. In particular, they found that foreign investors were attracted to China's real estate industry due to the demand created by foreign enterprises. Likewise, Bardhan and Kroll (2007) also noted that major U.S. real estate service firms and residential real estate brokerage firms follow U.S. multinational companies in developing countries in order to provide residential real estate services for expatriate population. He and Zhu (2010) found that foreign direct investors in real estate sector favored Chinese cities with more international tourists and more foreign investments. It is because both international tourists and foreign managers in foreign companies prefer to stay in hotels or apartments that provide offices (or easy access to them), accommodation, and eating facilities meeting Western standards. As a proxy for foreign investments in other sector, the sum of commercial and industrial property purchases by foreigners (FDI) per capita in each state is used. Information on this variable is taken from the Valuation and Property Service Department, Malaysia's Ministry of Finance.

Property Prices. Another determinant that is likely to have an impact on FIRP is the property prices. The rationale for selecting property prices as an independent variable is that real estate can be considered as financial assets, whose price changes would affect the quantity and direction of financial movements across borders. For instance, in their demand model for real estate in a foreign country, Rodríguez and Bustillo (2010) showed that there is a long-run and negative relationship between property prices and foreign real estate investment in Spain. In other words, they argued that demand for housing services abroad is negatively influenced by their prices. On the other hand, a number of researchers found that heightening property prices in the host countries encourages foreign investment in real estate sectors of those countries (He et al., 2009). For example, in their financial model for foreign real estate investment in Spain, Rodríguez and Bustillo (2010) found that there is a long-run and positive relationship between expectations of increasing prices for real estate assets and foreign real estate investments in Spain. In particular, they argued that Spain is attractive for real estate investment because the future return of the present investment is expected to be high. Similarly, as mentioned earlier, He et al. (2009) showed that the heightening housing prices significantly stimulate the inflow of FDI in China's real estate industry. In other words, they argued that foreign investors in real estate lean towards those (China) provinces with higher average housing prices. Therefore, we expect that Malaysian states with higher (lower) residential property prices attract lower (higher) amount of FIRP. Information on residential property prices is taken from the Valuation and Property Services Department, Malaysia's Ministry of Finance.

Tourism Agglomeration. We hypothesize that tourism agglomeration (learning about the host location) has a positive effect on FIRP. In other words, we expect that the higher level of knowledge about the attractiveness of the state lead to higher levels of FIRP. Previous studies also supported this hypothesis. For example, Rodríguez and Bustillo (2010) found that tourism agglomeration is a relevant factor explaining foreign real estate investment in Spain. In particular, they argued that investment in real estate by foreigners in Spain is influenced by the acquisition of information about the attractiveness of Spain as a holiday destination. In other words, tourism is considered as the first step before acquiring a 
property abroad. In a case study, Horner and Swarbrooke (2004) argued that most people who purchase property abroad do so in the country with which they have become familiar as tourists. In a descriptive and geographical study, Michalko and Ratz (2010) showed that most of the foreign investors in the Hungarian real estate market are those international tourists who had had pleasant experiences in Hungary before. The same results were found in the study of Gholipour and Masron (2011) on OECD countries. In this study, similar to the study by Rodríguez and Bustillo (2010), we use the number of international tourists, but lagged one period in order to take account of the time required to learn about the attractiveness of the host location. International hotel guests by state are used as a proxy for international tourism inbounds in each state. Data relating to the tourism is from the Ministry of Tourism Malaysia.

Well-being of Local People. Furthermore, we account for the well-being of local residents as an additional determinant of FIRP. This is consistent with existing literature on foreign investment. For example, Peterson et al. (1999) found that the location decisions of foreign investors are influenced by quality of life variables such as GDP per capita. Similarly, Kolstad and Villanger (2008) showed that GDP per capita is positively related to FDI in services (including real estate sector). Given above, it is expected that greater amount of FIRP are attracted to locations that have a higher level of well-being of local people. Following Weagraff (2004) and Dutta and Roy (2009), GDP per capita is used as a proxy for well-being of local residents ${ }^{4}$ in the present study. It should be noted that information on other determinants of quality of life is difficult to obtain at state level. Data pertaining

4 According to The Economist Intelligence Unit (2005), determinants of quality of life are: GDP per person, life expectancy at birth, political stability and security, divorce rate, community life, climate and geography, job security, political freedom and gender equality. to GDP per capita is obtained from the Malaysia's Department of Statistics.

Religious Diversity. Another important factor that would affect the locational patterns of FIRP in Malaysia is religious diversity. Since religious diversity influence investors' decisions where to invest (Dolansky and Alon, 2008), therefore, we hypothesis that FIRP should be higher in Malaysian states in which religious diversity is higher. This is motivated by the findings of Dolansky and Alon (2008) who found that religious diversity stimulate FDI. They argued that less tolerant and diverse countries could be less naturally open to international participation. In another study, Barro and McCleary (2003) concluded that greater religious diversity leads to greater economic growth. In the present study, following Dolansky and Alon (2008), states' scores on the religious pluralism index are adapted from the Herfindal Index in order to measure religious diversity. This index ranges from 0 to 1 . A score of "1" indicates great diversity and a zero indicates complete religious homogeneity. We calculate the index for each of the Malaysian state. In order to include this variable in our empirical model, we make a binary dummy variable. The dummy equals to one if the score is 0.50 and above and zero otherwise.

According to the Malaysian constitution, Islam is the religion of the country but other religions (particularly, Buddhism, Hinduism and Christianity) practice in peace and harmony. Our calculations for the pluralism index indicate that Kuala Lumpur, Pulau Pinang, Sarawak and Selangor have highest religious diversity.

Minimum Purchase Prices. Finally, minimum purchase prices (MPP) for foreign property buyers should be taken into account as an important location-specific determinant of FIRP. It is because the MPP is not standardized among Malaysian states. It expected that FIRP in Malaysia responds to the state differences in terms of MMP. It is because each of the Malaysian states has different policy on the 
MMP. For example, the MPP for foreigners in Johor is RM 500,000. Pahang state set a minimum price of RM 750,000. Sarawak set the minimum price for foreigners at RM 350,000 (Davison, 2011). For this factor, we include a dummy variable in our empirical model (zero if MMP is less than RM 500,000 and one for MMP equals RM 500,000 and above).

Given the earlier discussion, the following panel data model is specified:

$\operatorname{lnFIRP}{ }_{i t}=80+81 \operatorname{lnINFRAS}_{i t}+82 \operatorname{lnFDI}_{\text {it }}+$ $83 \operatorname{lnPPRIC} \mathrm{it}_{1}+84 \operatorname{lnTOUR}_{\mathrm{i}(\mathrm{t}-1)}+85 \operatorname{lnGDPcap}_{\mathrm{it}}$ + 86 RELIG $_{\mathrm{i}}+87 \mathrm{MPP}_{\mathrm{i}}+\mathrm{e}_{\mathrm{it}}$,

where: FIRP $_{\text {it }}$ stands for foreign investments in residential properties in state $i$ and period

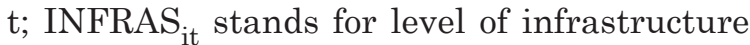
in state $\mathrm{i}$ and period $\mathrm{t}$; $\mathrm{FDI}_{\mathrm{it}}$ represents foreign investments in other sectors in state $i$ and period t; PPRIC $_{\text {it }}$ denotes the residential property price for state $\mathrm{i}$ and period $\mathrm{t}$; TOUR $_{\mathrm{i}(\mathrm{t}-1)}$ denotes the number of international tourists arrivals in state $\mathrm{i}$ in period $\mathrm{t}-1$; GDPcap $_{\text {it }}$ represents the well-being of local residents for state $i$ and period $t$; RELIG ${ }_{i}$ is the religious diversity for state $i$; $M P_{i}$ is the minimum purchase price for state $i$ and $e_{i t}$ is an error term.

\section{METHODOLOGY}

The main purpose of this paper is to investigate the determinants of FIRP in Malaysian states. In the present study, the panel data technique is applied to estimate the relationships between the explanatory variables and FIRP. The panel data consists of 14 Malaysian states over 7 years (2004-2010). The relatively small size of the sample is due to the limited availability of the FIRP and tourism.

This is an unrealistic assumption if we suppose that the explanatory variables are exogenous (variables that are not correlated with the residuals). For example, greater amount of foreign investments in real estate contribute to economic development and higher level of GDP (e.g. Ning and Yu, 2009). Likewise, the increased foreign real estate investments raise the tourism in the host location because tourism is the following step after acquiring a property (e.g. Rodríguez and Bustillo, 2010). Therefore, at the presence of endogeneity problem, a simple OLS would lead to biased estimates.

The standard approach in cases where right-hand side variables are correlated with the residuals (or endogeneity problem) is to estimate the equation using instrumental variables regression, particularly Generalized Method of Moments (GMM).

Another econometric problem is that timeseries regression analysis may involve autocorrelation of the disturbances or serial correlation. We can solve this econometric problem (autocorrelation) by including the lagged dependent variable on the right hand side of the regression equations (Busse and Hefeker, 2007; Cheng and Kwan, 2000). In doing so, by using lagged FIRP in the equation, the econometric specification will be changed to a dynamic panel. A usual method for dynamic panels is the GMM estimator. Arellano and Bond (1991) and Arellano and Bover (1995) suggested first-differencing the model to eliminate the unobserved effects and then using valid instruments to deal with the problem of the new error term being correlated with the lagged dependent variable.

A drawback of the difference GMM is that when first differences are taken, time-invariant variables are removed. Therefore, the first difference GMM does not use the cross-sectional information reflected in the differences between states. Another disadvantage of first difference GMM is that lagged levels are often poor instruments for the equation in difference, which can lead to poor precision in the estimators. To mitigate this problem, a new estimator is used, namely, the system GMM, developed by Arellano and Bover (1995) and Blundell and Bond (1998). This estimator is based on an augmented system that includes the regression in differences and in addition to the regression in the levels with lagged differences as instruments (Bajo-Rubio et al., 2010). 
Thus, we use the system GMM estimator to investigate the relationships between explanatory variables and FIRP.

The use of valid instruments is required in order to control for the potential endogeneity of the other explanatory variables. The consistency of the GMM estimator depends on the validity of the instruments, which is examined by means of two specifications tests (Arellano and Bond, 1991). First, the Sargan test statistic of over-identifying restrictions (that tests the hypothesis that the instrument variables are not correlated with the residuals). The validity of the instrument variables should not be rejected by Sargan test. Second, we need to test the null hypothesis of no second-order correlation in the residuals (Bajo-Rubio et al., 2010). In order to have consistent GMM estimators, the null hypothesis of no second-order serial correlation should not be rejected.

\section{ESTIMATION RESULTS}

Table 4 presents the results of the GMM system regression. The statistical findings do not prove all the hypotheses put forward.

The results show that INFRAS variable is not significant at 5\% level, suggesting that infrastructure is not a critical factor in determining the FIRP in Malaysian states. It may be due to the well-developed infrastructure of Malaysian states which does not show high variation over time. This finding does not provide support for previous studies such as Chin et al. (2006) who argued that locations with established infrastructure would attract greater amounts of foreign investments in property sector.

Moreover, we find that FDI is positively associated with FIRP, indicated by an estimated coefficient that is significant at the $1 \%$ level. It means that states with higher level of foreign investments in other sectors would have greater amount of FIRP. That is to say that FIRP in Malaysia has been agglomerated in the major and industrialized states (such as Kuala Lumpur, Pulau Pinang, Selangor and
Table 4. GMM system regression results

\begin{tabular}{ll}
\hline Dependent variable: FIRP & \\
\hline Independent variables & Model $(1)$ \\
\hline lnINFRAS $_{\mathrm{it}}$ & -0.0066 \\
& $(-0.0515)$ \\
$\operatorname{lnFIRP}_{\mathrm{i}(\mathrm{t}-1)}$ & -0.4598 \\
& $(-3.9765)^{* * *}$ \\
$\operatorname{lnFDI}_{\mathrm{it}}$ & 0.0796 \\
& $(2.3937)^{* * *}$ \\
$\operatorname{lnPPRIC}_{\mathrm{it}}$ & -1.1383 \\
& $(-1.1596)$ \\
$\operatorname{lnTOUR}_{\mathrm{i}(\mathrm{t}-1)}$ & 0.5512 \\
& $(6.0710)^{* * *}$ \\
$\operatorname{lnGDPcap}_{\mathrm{it}}$ & 1.3466 \\
& $(2.4020)^{* *}$ \\
RELIG $_{\mathrm{i}}$ & 3.1002 \\
& $(8.3167)^{* * *}$ \\
MPP $_{\mathrm{i}}$ & -2.1124 \\
& $(-6.8242)^{* * *}$ \\
S.E. of regression & 0.3941 \\
Test $p$-values & \\
Sargan & 0.3639 \\
AR (2) & 0.4650 \\
\hline
\end{tabular}

Note: Significant at: ${ }^{*} 10,{ }^{* *} 5$ and $* * * 1 \%$. t statistics are reported in parentheses.

Johor). This result is consistent with previous studies (e.g. Moshirian and Pham, 2000; He and Zhu, 2010).

The coefficient for PPRIC has a negative sign, meaning that housing prices are negatively associated with FIRP, but is not significant. The result for PPRIC indicates that foreign property purchasers are not too sensitive to changes in residential property prices. In other words, foreign investors in the residential property sector appear indifferent to property prices in the Malaysian states. One reason could be that most of the foreign investors in Malaysian residential properties are involved in Malaysia My Second Home (MM2H) program and they just want to have a dwelling for living rather than considering the investment issues.

In addition, we find that tourism agglomeration (TOUR-1) is positively associated with FIRP, shown by an estimated coefficient that 
is significant at the $1 \%$ level. It means that the higher level of knowledge about the attractiveness of a state in the previous period would lead to higher level of FIRP in current period. This finding is concurring with other similar studies (e.g. Gholipour and Masron, 2011; Rodríguez and Bustillo, 2010).

The results also show that coefficient for GDPcap is positive and significant at 5\% level, indicating that states with higher level of GDP per capita (prosper people) tend to attract higher FIRP, in line with our hypothesis. This finding is also consistent with Peterson et al. (1999).

Interestingly, we find that FIRP is higher in Malaysian states in which religious diversity (RELIG) is higher, in line with the hypothesis we put forward. This is also consistent with the findings of Dolansky and Alon (2008) who found that high tolerant and diverse countries attract greater amount of FDI. Kuala Lumpur and Pulau Pinang (which have high level of religious diversity and FIRP) are two examples to confirm our result.

Finally, the minimum property purchase price (MMP) variable has a significant and negative relationship with FIRP at the 5\% level, indicating that states with higher level of MMP would receive lower FIRP. This result confirms the hypothesis put forward which MMP is an important determinant of FIRP in Malaysia.

The Sargan test $(p$-value $=0.3639)$ shows that the applied instruments are valid (see Table 4). The residuals also do not exhibit secondorder serial correlation, as shown by an insignificant $p$-value of AR (2). Thus, neither of the test statistics leads us to reject the assumption of consistency of the GMM estimator.

To sum up, states with greater amounts of foreign investments in other sectors, larger number of international tourists, higher level of income per capita, higher level of religious diversity and lower minimum property purchase price have greater amount of FIRP.

\section{CONCLUSION}

The last decade has witnessed a strong growth in residential property purchases by foreigners (FIRP) in Malaysia. However, FIRP is not equally distributed among Malaysian states. Using data from the Valuation and Property Service Department (under Malaysia's Ministry of Finance) during 2004 and 2010, the empirical results show that FIRP in Malaysia has been agglomerated in the major and industrialized states such as Kuala Lumpur, Pulau Pinang, Selangor and Johor. The main purpose of this study has been to understand the driving forces of FIRP locations in Malaysia by using data on FIRP in Malaysian states during 2004-2010. Applying GMM panel data estimation, we find that states with greater amount of foreign investments in other sectors, larger number of international tourists in the previous period, higher level of GDP per capita, higher level of religious diversify and lower minimum property purchases price have greater amounts of FIRP during the period of study. In addition, we find no significant relationship between property prices and FIRP.

The econometric analysis clearly suggests that foreign investors in Malaysia's residential properties pay more attentions to culture, religion, prosperity of the local people and agglomeration effects to make property investment decisions. An important implication that can be drawn from our results is that policymakers in Malaysian states need to promote the tourism attractiveness of their own state in order to receive larger amount of FIRP. In addition, states' policymakers can increase the FIRP in their states by decreasing the minimum property purchase prices.

Finally, it should be noted that the present study only considered the aggregate FIRP for analysis. For future research, it may be useful to analyze the FIRP by using disaggregate data of FIRP that come from different regions and countries because the foreign investors in Malaysia's residential properties come from 
variety of countries which have different level of economic development and cultural attitudes. Moreover, future research may divide the corporate real estate acquisitions and individual acquisitions to investigate the relationship between explanatory variables and FIRP if the data is available.

\section{REFERENCES}

Anop, S. (2010) Determinants of foreign direct investment in real estate in European countries - panel data analysis. In: Proceedings of the 17th ERES conference, 23-26 June, 2010, Milan, Italy.

Arellano, M. and Bond, S. (1991) Some tests of specification for panel data: Monte Carlo evidence and an application to employment equations, Review of Economic Studies, 58(2), pp. 277-297. http://dx.doi. org/10.2307/2297968

Arellano, M. and Bover, O. (1995) Another look at the instrumental variable estimation of error-components models, Journal of Econometrics, 68(1), pp. 29-51. http://dx.doi.org/10.1016/0304-4076(94)01642-D

Bajo-Rubio, O., Díaz-Mora, C. and Díaz-Roldán, C. (2010) Foreign direct investment and regional growth: an analysis of the Spanish case, Regional Studies, 44(3), pp. 373-382. http://dx.doi. org/10.1080/00343400802508844

Bardhan, A. and Kroll, C. A. (2007) Globalization and the real estate industry: issues, implications, opportunities, Industry Studies Working Paper 2007-04. [Online] Available at: http://web.mit.edu/sis07/www/ kroll.pdf

Barro, R. J. and McCleary, R. M. (2003) Religion and economic growth across countries, American Sociological Review, 68(5), pp. 760-781. http://dx.doi. org/10.2307/1519761

Basu, B. and Yao, J. (2009) Foreign direct investment and skill formation in China, International Economic Journal, 23(2), pp. 163-179. http://dx.doi. org/10.1080/10168730902901106

Blundell, R. and Bond, S. (1998) Initial conditions and moment restrictions in dynamic panel data models, Journal of Econometrics, 87(1), pp. 115-143. http:// dx.doi.org/10.1016/S0304-4076(98)00009-8

Busse, M. and Hefeker, C. (2007) Political risk, institutions and foreign direct investment, European Journal of Political Economy, 23(2), pp. 397-415. http:// dx.doi.org/10.1016/j.ejpoleco.2006.02.003

Cheng, L. K. and Kwan, Y. K. (2000) What are the determinants of the location of foreign direct investment? The Chinese experience, Journal of International Economics, 51(2), pp. 379-400. http://dx.doi. org/10.1016/S0022-1996(99)00032-X
Chin, W., Dent, P. and Roberts, C. (2006) An exploratory analysis of barriers to investment and market maturity in Southeast Asian cities, Journal of Real Estate Portfolio Management, 12(1), pp. 49-57.

Davison, J. A. (2011) The expat property guide. The Expat Group.

Dutta, N. and Roy, S. (2009) The impact of foreign direct investment on press freedom, Kyklos, 62(2), pp. 239-257. http://dx.doi.org/10.1111/j.14676435.2009.00434.x

Dolansky, E. and Alon, I. (2008) Religious freedom, religious diversity, and Japanese foreign direct investment, Research in International Business and Finance, 22(1), pp. 29-39. http://dx.doi.org/10.1016/j. ribaf.2006.11.003

Economist Intelligence Unit (2005) The Economist Intelligence Unit's quality-of-life index. Economist Intelligence Unit.

Economic Planning Unit (2010) Guideline on the acquisition of properties. Prime Minister's Department Malaysia.

Edgington, D. W. (1996) Japanese real estate investment in Canadian cities and regions, 1985-1993, Canadian Geographer-Geographe Canadien, 40(4), pp. 292-305. http://dx.doi.org/10.1111/j.1541-0064.1996.tb00458.x

Faeth, I. (2009) Determinants of foreign direct investment - a tale of nine theoretical models, Journal of Economic Surveys, 23(1), pp. 165-196. http://dx.doi. org/10.1111/j.1467-6419.2008.00560.x

Falkenbach, H. (2009) Market selection for international real estate investments, International Journal of Strategic Property Management, 13(4), pp. 299-308. http://dx.doi.org/10.3846/1648-715X.2009.13.299-308

Ford, D. A., Fung, H. and Gerlowski, D. A. (1998) Factors affecting foreign investor choice in types of U.S. real estate, Journal of Real Estate Research, 16(1), pp. 99-112.

Fung, H. G., Jeng, J. L. and Liu, Q. W. (2010) Development of China's real estate market, The Chinese Economy, 43(1), pp. 71-92.

Gholipour, H. F. and Masron, T. A. (2011) The effect of tourism agglomeration on foreign real estate investment: evidence from OECD countries, International Journal of Strategic Property Management, 15(3), pp. 222-230. http://dx.doi.org/10.3846/164871 5X.2011.613241

Gholipour, H. F., Masron, T. A., Malekmohammadi, A. and Ooi, A. Y. (2010) The interaction between foreign real estate investment and tourism: the Iranian case in Dubai, World Applied Sciences Journal, 10, pp. 40-44.

He, C., Wang, J. and Cheng, S. (2011) What attracts foreign direct investment in China's real estate development?, Annals of Regional Science, 46(2), pp. 267293. http://dx.doi.org/10.1007/s00168-009-0341-4 
He, C. and Zhu, Y. (2010) Real estate FDI in Chinese cities: local market conditions and regional institutions, Eurasian Geography and Economics, 51(3), pp. 360384. http://dx.doi.org/10.2747/1539-7216.51.3.360

Hines, M. A. (2001) Investing in international real estate. Greenwood Publishing Group, USA.

Horner, S. and Swarbrooke, J. (2004) International cases in tourism management. Elsevier, England.

Holsapple, E. J., Ozawa, T. and Olienyk, J. (2006) Foreign "direct" and "portfolio" investment in real estate: an eclectic paradigm, Journal of Real Estate Portfolio Management, 12(1), pp. 37-47.

Jiang, D., Chen, J. J. and Isaac, D. (1998) The effect of foreign investment on the real estate industry in China, Urban Studies, 35(11), pp. 2101-2110. http://dx.doi. org/10.1080/0042098984024

Lai, P. P. and Fischer, D. (2007) The determinants of foreign real estate investment in Taiwan, Pacific Rim Property Research Journal, 13(3), pp. 263-279.

Lee, L. S., Choong, W. W. and Rosdi, B. A. R. (2010) Ten years review of Malaysia My Second Home Programme (MM2H). In: International Real Estate Research Symposium, 27-29 April, 2010, Kuala Lumpur, Malaysia.

Kolstad, I. and Villanger, E. (2008) Determinants of foreign direct investment in services, European Journal of Political Economy, 24(2), pp. 518-533. http:// dx.doi.org/10.1016/j.ejpoleco.2007.09.001

Mani, U. (2006) Real estate in Malaysia: Challenges, insights, and issues. Malaysia, Kuala Lumpur: Faculty of Built Environment, University of Malaya.

Michalko, G. and Ratz, T. (2010) Hungarian spa destinations in the tourism-oriented property market, Hungarian Geographical Bulletin, 59(2), pp. 131-146.

MM2H (2011) Malaysian My Second Home Programme. [Online] Available at: http://www.mm2h.gov.my/statistic.php

Moshirian, F. and Pham, T. (2000) Determinants of US investment in real estate abroad, Journal of $\mathrm{Mul}$ tinational Financial Management, 10(1), pp. 63-72. http://dx.doi.org/10.1016/S1042-444X(99)00019-5

Newell, G. and Worzala, E. (1995) The role of international property in investment portfolios, Journal of Property Finance, 6(1), pp. 55-63. http://dx.doi. org/10.1108/09588689510088186

Ning, J. and Yu, B. (2009) The analysis on FDI's technology spillover based on industrial relationship: China's real estate industry as an example. In: Proceedings of 2009 international conference on construction \& real estate management, 5-6 November, 2009, Beijing, China, Vols. 1 and 2, pp. 1266-1269.

Peterson, M., Malhota, N. K. and Wagner, J. (1999) Country quality of life and foreign direct investment decisions, Global Outlook, 11, pp. 51-62.

Propertywire (2011) Middle Easter buyers increasing in Malaysia, research suggests. [Online] Available at: http://www.propertywire.com/news/asia/malaysiabuyers-middle-east-201109275612.html

Ramasamy, B. and Yeung, M. (2010) The determinants of foreign direct investment in services, World Economy, 33(4), pp. 573-596. http://dx.doi.org/10.1111/ j.1467-9701.2009.01256.x

Renaud, B. (2010) Dubai's real estate boom and bust of 2002-2008: dynamics and policy responses, Housing Finance International, 24(4), pp. 6-17.

Rodríguez, C. and Bustillo, R. (2010) Modeling foreign real estate investment: the Spanish case, Journal of Real Estate Finance and Economics, 41(3), pp. 354-367. http://dx.doi.org/10.1007/s11146-008-9164-9

Tan, P. V. (1998) Foreign ownership in Malaysia - a look at issues, Journal of Valuation and Property Services, 1(1).

Weagraff, B. S. (2004) The contribution of second homes to rural economies. Master Thesis. The Pennsylvania State University.

Wei, Y. D., Leung, C. K. and Luo, J. (2006) Globalizing Shanghai: foreign investment and urban restructuring, Habitat International, 30(2), pp. 231-244. http:// dx.doi.org/10.1016/j.habitatint.2004.02.003

Worzala, E. (1994) Overseas property investments: how are they perceived by the institutional investor?, Journal of Property Valuation and Investment, 12(3), pp. 3147. http://dx.doi.org/10.1108/14635789410063904

Wu, F. (2001) China's recent urban development in the process of land and housing marketisation and economic globalization, Habitat International, 25(3), pp. 273-289. http://dx.doi.org/10.1016/S0197. 3975(00)00034-5

Zhu, J., Sim, L. and Zhang, X. (2006) Global real estate investments and local cultural capital in the making of Shanghai's new office locations, Habitat International, 30(3), pp. 462-481. http://dx.doi.org/10.1016/j. habitatint.2004.12.003 